University of Nebraska - Lincoln

DigitalCommons@University of Nebraska - Lincoln

2012

\title{
Conservation Implications When the Nest Predators Are Known
}

Frank Thompson

USDA Forest Service Northern Research Station, frthompson@fs.fed.us

C.A. Ribic

Wisconsin Cooperative Wildlife Research Unit, caribic@wisc.edu

Follow this and additional works at: https://digitalcommons.unl.edu/usgsnpwrc

Part of the Other International and Area Studies Commons

Thompson, Frank and Ribic, C.A., "Conservation Implications When the Nest Predators Are Known" (2012). USGS Northern Prairie Wildlife Research Center. 260.

https://digitalcommons.unl.edu/usgsnpwrc/260

This Article is brought to you for free and open access by the US Geological Survey at DigitalCommons@University of Nebraska - Lincoln. It has been accepted for inclusion in USGS Northern Prairie Wildlife Research Center by an authorized administrator of DigitalCommons@University of Nebraska - Lincoln. 


\title{
Conservation Implications When the Nest Predators Are Known
}

\author{
Frank R. Thompson III, and Christine A. Ribic
}

Abstract. Conservation and management of passerines has largely focused on habitat manipulation or restoration because the natural communities on which these birds depend have been destroyed and fragmented. However, productivity is another important aspect of avian conservation, and nest predation can be a large source of nesting mortality for passerines. Recent studies using video surveillance to identify nest predators allow researchers to start evaluating what methods could be used to mitigate nest predation to help passerines of conservation concern. From recent studies, we identified latitudinal and habitat-related patterns in the importance of predator groups that depredate passerine nests. We then reviewed how knowledge of specific nest predators can benefit conservation of bird species of concern. Mammals were the dominant predator group in northern grasslands. Snakes were the dominant predator group in southern habitats. Fire ants were only a nest predator in southern latitudes. Differences in the importance of predator species or groups were likely the result of both their geographic patterns of distribution and habitat preferences. Some direct and indirect predator control measures developed for waterfowl management potentially could be used to benefit passerine productivity. We reviewed three examples--cowbirds, snakes in shrublands, and ground squirrels in grasslands-to illustrate how different predator control strategies may be needed in different situations. Mitigation of passerine nest predation will need to be based on knowledge of predator communities to be effective. This requires large samples of predation events with identified predators; video technology is essential for this task.

Key Words: conservation, cowbirds, forest, grassland, mesopredators, nest predators, passerines, shrubland, snakes, video technology.

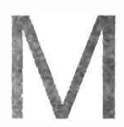
any bird species have suffered loss, degradation, and fragmentation of the habitats on which they depend (e.g., Askins et al. 2007). As a result, conservation efforts on behalf of these birds have largely focused on habitat manipulations or restoration. However, population status of birds is not totally determined by habitat factors. One particularly important aspect of avian ecology is productivity, and nest predation can be a large source of nesting mortality, especially for passerines (Ricklefs 1969; Martin 1988, 1995; Newton 1998; Thompson 2007). Not knowing who the nest predators actually

Thompson, F. R., III, and C. A. Ribic. 2012. Conservation implications when the nest predators are known. Pp. 23-34 in C. A. Ribic, F. R. Thompson III, and P. J. Pietz (editors). Video surveillance of nesting birds. Studies in Avian Biology (no. 43), University of California Press, Berkeley, CA. 
are can affect not only our understanding of the ecology of birds but also conservation and management actions (Nelson 2001, Thompson 2007, Lahti 2009). Integrating knowledge of predation into management has been addressed in reviews for harvested bird species (e.g., waterfowl, Sovada et al. 2001; ground-nesting gamebirds, Jimenez and Conover 2001); however, the only passerine group to be considered so far are neotropical migrant songbirds (Heske et al. 2001). One issue raised by Heske et al. (2001) for this group was the diversity of potential predator species and how to manage them.

Recent studies using video surveillance on passerine nests have made significant contributions toward identifying nest predators, which has started to help us assess the relative importance of different predator taxa in different habitats in North America (Benson et al. 2010, Reidy and Thompson, chapter 11, this volume, Ribic et al., chapter 10 , this volume). These findings provide us the opportunity to start evaluating how this information can help us with large-scale conservation and management. In other words, given what we know about the nest predators, what is the potential to mitigate nest predation to help passerines of conservation concern?

Unfortunately, comparison of predation among studies to illustrate larger-scale patterns is hampered by the way many results have been reported. Most studies documenting the identity of nest predators present counts of predation events by species or groups of species. Counts of predation events can be compared within a study to assess the relative importance of predators but are not directly comparable across studies because of differences in camera nest-days (i.e., the number of days active nests were monitored with video surveillance systems). Another limitation is that counts of predation events do not represent actual nest mortality rates. One alternative to the use of counts is the use of multinomial logistic regression models to estimate the daily probability of predation events resulting from different predators (Thompson and Burhans 2003). These probabilities are analogous to daily, causespecific mortality rates and can be directly compared across studies to illustrate larger-scale patterns in predator dominance or even absolute mortality rates by specific predators.

In this paper we address two questions: (1) Are there geographic and habitat-related patterns in the importance of nest predator species or groups for passerines of conservation concern; and (2) how can knowledge of specific nest predators benefit conservation of bird species of concern? To address the first question, we reanalyze data from some existing studies in various parts of the midwestern and southern United States to make direct comparisons of the risk of predation by predator groups (not possible with the original results) which illustrate larger-scale patterns. For the second question, we review different strategies for managing nest predation based on work done on waterfowl, and then present examples relevant to passerines: two in shrubland and forest habitats and one in grasslands.

\section{PATTERNS IN IMPORTANCE OF PASSERINE NEST PREDATORS IN THE MIDWESTERN AND SOUTHERN U.S.}

\section{Methods}

We used five data sets from camera studies of passerine nest predation in the midwestern and southern U.S. that spanned a wide geographic range, represented multiple habitats, and were among the largest studies published (Fig. 2.1). Because of this post-study selection and stratification, geography and habitat are somewhat confounded, but nevertheless we believe the comparisons are useful. The data sets represent North Dakota and Minnesota (hereafter North Dakota) grasslands, Wisconsin grasslands, Missouri shrubland and forest, Texas shrubland and forest, and Georgia forest. The North Dakota grassland data were from 1996-2000 and consisted of 1,187 camera nest-days (Pietz et al., chapter 1, this volume; Granfors, pers. comm.). Dominant nesting species were Clay-colored Sparrow (Spizella pallida) and Savannah Sparrow (Passerculus sandwichensis); other common species included Bobolink (Dolichonyx oryzivorus), Vesper Sparrow (Pooecetes gramineus), and Chestnutcollared Longspur (Calcarius ornatus). Dominant habitats were native and planted grasslands, consisting of grasses, forbs, and small shrubs. The Wisconsin grasslands data were from 1998-2008 and consisted of 2,404 camera nest-days (Pietz et al., chapter 1 , this volume). Dominant nesting species were Eastern Meadowlark (Sturnella magna), Grasshopper Sparrow (Ammodramus savannarum), Bobolink, and Savannah Sparrow. Dominant habitats were continuously grazed pasture consisting of cool-season grasses, primarily Kentucky bluegrass (Poa pratensis); Conservation Reserve Program fields consisting of cool-season grasses, primarily smooth 
North Dakota/Minnesota (Pietz et al., chapter 1, this volume)

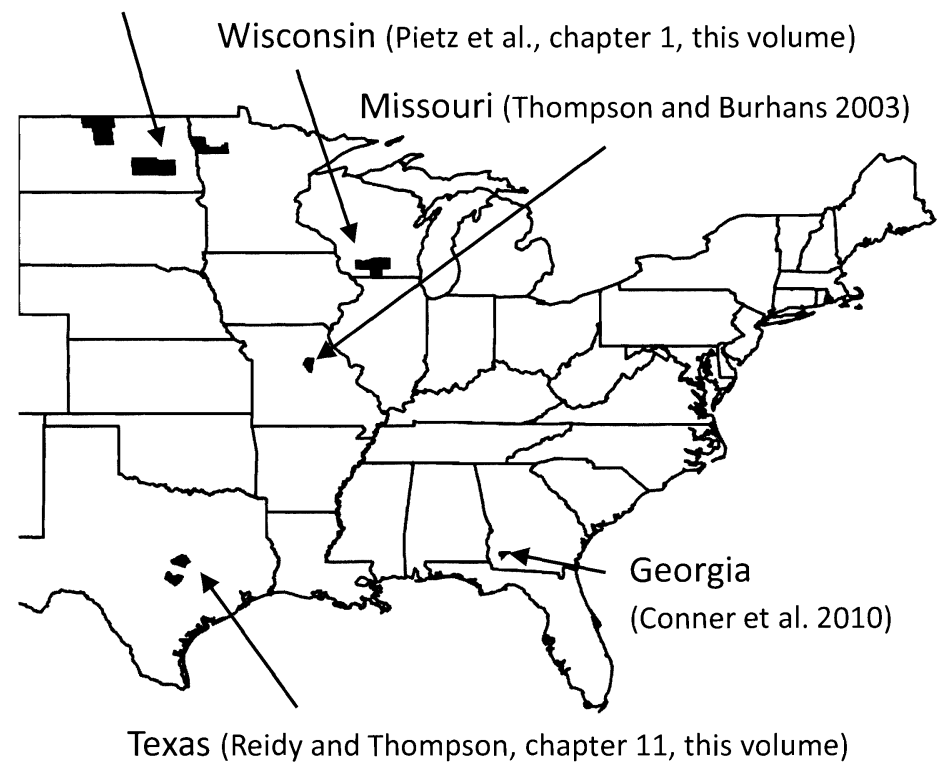

Figure 2.1. Locations of studies that used video surveillance of passerine nests in the midwestern and southern United States. We reanalyzed data from these studies to compare daily predation rates of passerine nests in grasslands, shrublands, and forests by five predator groups.

brome (Bromus inermis); and remnant prairie consisting of native warm-season grasses, such as little bluestem (Schizachyrium scoparium), big bluestem (Andropogon gerardii), needle (porcupine) grass (Heterostipa spartea), and Indian grass (Sorghastrum nutans). The Missouri shrubland and forest data were from 1997-1999 and consisted of 1,500 camera nest-days (Thompson and Burhans 2003). Dominant nesting species were Field Sparrow (Spizella pusilla), Indigo Bunting (Passerina cyanea), Kentucky Warbler (Oporornis formosus), Worm-eating Warbler (Helmitheros vermivorus), Ovenbird (Seiurus aurocapillus), Acadian Flycatcher (Empidonax virescens), and Wood Thrush (Hylocichla mustelina). Dominant habitats were old fields consisting of grasses, forbs, and shrubs and oak (Quercus spp.)-hickory (Carya spp.) forest. The Texas shrubland and forest data were from 1997-2009 and consisted of 3,346 camera nest-days (Reidy and Thompson, chapter 11, this volume). Dominant nesting species were Black-capped Vireo (Vireo atricapilla) and Golden-cheeked Warbler (Setophaga chrysoparia). Dominant habitats were short scrubland dominated by oaks (Quercus spp.) and Ashe juniper (Juniperus ashei)-oak woodlands. The Georgia forest data were from 2003-2006 and consisted of 2,486 camera nest-days (Conner et al. 2010). Dominant nesting species were Northern Cardinal (Cardinalis cardinalis), Brown Thrasher
(Toxostoma rufum), Eastern Towhee (Pipilo erythrphthalmus), Blue Grosbeak (Guiraca caerulea), and Indigo Bunting. Dominant habitats were longleaf (Pinus palustris), slash (P. elliottii), and loblolly ( $P$. taeda) pine forest and mixed pine and hardwood forest.

The data consisted of an observation for each nest-day represented by six possible fates: predation by (1) raptors/corvids, (2) Brown-headed Cowbirds (Molothrus ater), (3) fire ants (all most likely the imported red fire ant, Solenopsis invicta), (4) mammals, or (5) snakes; and (6) other (i.e., success, failure due to other causes, or unknown). A nest could suffer multiple fates involving partial predation by one or more predators, so predation rates should be interpreted as the probability of partial or complete predation by the specific predator group. We used the "other" fate category as our reference category because our interest was to estimate rates of loss to specific predator groups. For each data set, we fit a multinomial regression model (PROC Logistic, SAS ver. 9.2, SAS Institute, Cary, NC) with response categories representing the six fates to estimate the daily probability and $95 \%$ confidence interval of each fate (Thompson and Burhans 2003). This approach was only possible because of video monitoring; we knew the 


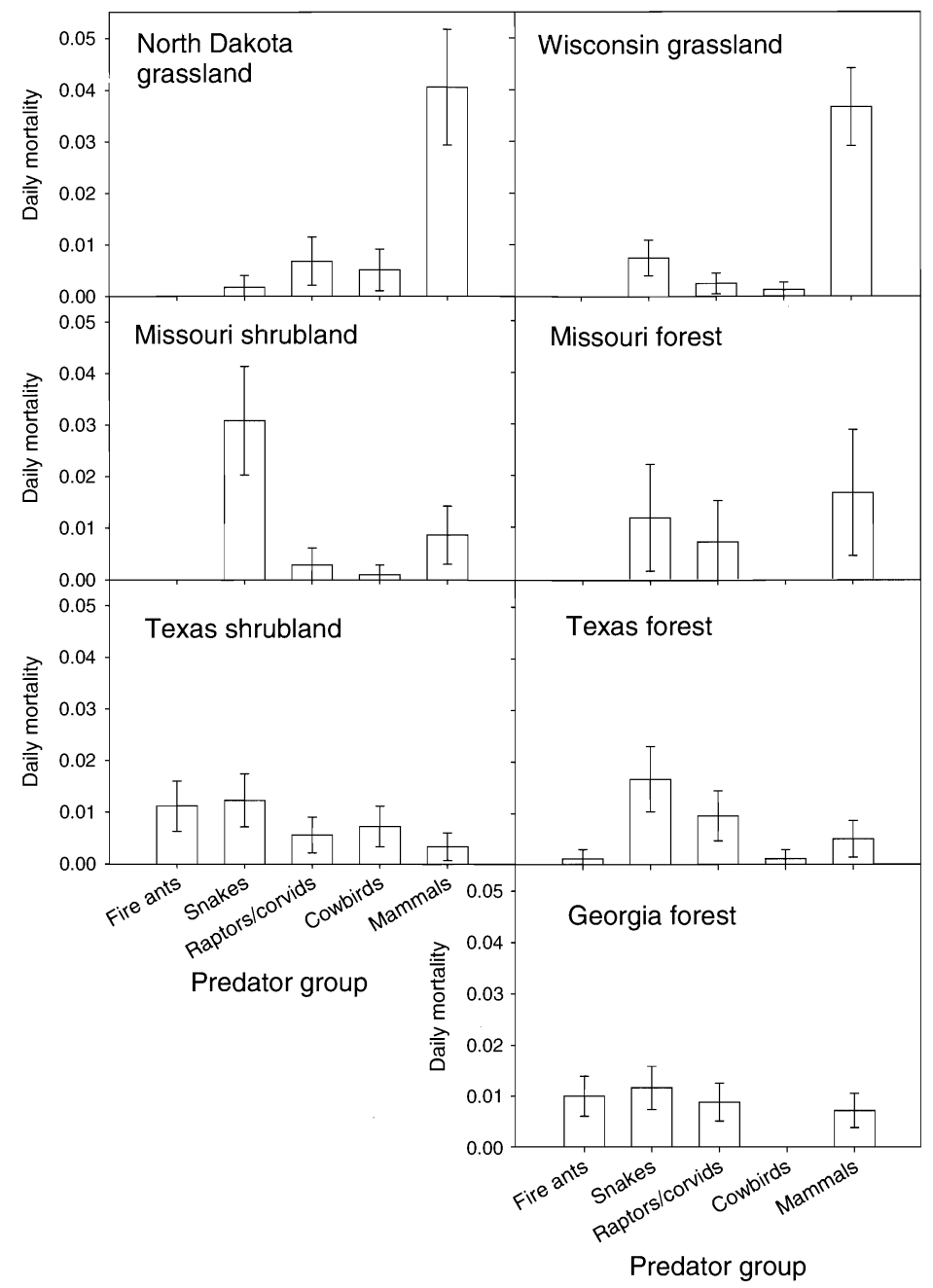

Figure 2.2. Daily nest mortality (95\% CI) among habitats and predator groups in the midwestern and southern United States. Data are 1,187 and 2,404 camera nest-days in North Dakota/Minnesota and Wisconsin, respectively (Pietz et al., chapter 1, this volume); 3,346 camera nest-days in Texas (Reidy and Thompson, chapter 11, this volume); 1,500 camera nest-days in Missouri (Thompson and Burhans 2003); and 2,486 camera nest-days in Georgia (Conner et al. 2010).

fates of each nest on each day it was monitored. The models for Missouri and Texas included an intercept and covariate for habitat type (forest or shrubland); for North Dakota, Wisconsin, and Georgia the model only included an intercept because the data were from only one general habitat type (grasslands or forest). We did not examine more complex relationships with covariates because these are addressed by the original individual studies, and our objective was to examine regional patterns in the average probability of predation by each of the five predator groups.

\section{Results and Discussion}

We estimated the daily probability of predation by each of the five predator groups for each data set. There were patterns in the probability of predation by raptors/corvids, Brown-headed Cowbirds, fire ants, mammals, and snakes that emerged from our analysis (Fig. 2.2). Several patterns appeared related to latitude. Mammals were the dominant predator group in northern grasslands (North Dakota, Wisconsin). Snakes were the dominant predator group in southern habitats (Texas, Georgia). Fire ants were a unique and important predator in the 
southern latitudes. The southern latitudes also had a more even distribution among predator groups than the northern latitudes (Fig. 2.2).

The decrease in the importance of snakes as a nest predator in northern latitudes is consistent with geographic patterns in snake distributions. While numbers of all species tend to decrease with latitude in North America, numbers of ectotherms decline more steeply than endotherms, and numbers of snake species are negatively correlated with numbers of mammal and bird species (Schall and Pianka 1978). The most commonly detected snake group was the ratsnake (Pantherophis spp.); this group is at its northern range limit in Wisconsin (Christoffel et al. 2000) and does not occur on the Wisconsin study sites or in North Dakota (Trepanowski 2003). In Wisconsin, snakes such as the western foxsnake (Mintonius vulpinus) and gartersnake (Thamnophis spp.) were responsible for grassland bird nest predation, but at a much lower rate than mammals.

Fire ants were only a nest predator in southern latitudes. The imported red fire ant was introduced in Alabama in the 1930s and has spread throughout most of the southern U.S. (Allen et al. 2004). Hence, the pattern in their importance as a nest predator reflects their distribution.

Another geographic pattern relates to cowbirds. Cowbirds were predators at all sites except for forests in Missouri and Georgia (Fig. 2.2). This is somewhat consistent with patterns in their breeding abundances; they are most abundant in the Great Plains and Midwest, with decreasing abundance moving coastward. This pattern in abundance likely reflects their historic distribution in the Great Plains and expansion across North America (Thompson et al. 2000). However, the geographic pattern in the importance of cowbirds as brood parasites (and, by extension, nest predators) may be confounded by habitat (Igl and Johnson 2007).

Other patterns were related to habitat. In the northern grasslands, predation rates by group were very similar for the two areas. At mid-latitudes (Missouri), the most important predator group shifted from snakes in shrublands to mammals in forests, largely due to greater predation by raccoons (Procyon lotor) in forests. The biggest difference among habitats in Texas was the increased importance of cowbirds and fire ants in shrubland; however, in contrast to Missouri, snakes were equally or even slightly more important in forests. These differences all relate to habitat preferences of the predators. Snakes, especially ratsnakes, prefer edge because of benefits for thermoregulation (Blouin-Demers and Weatherhead 2001). The habitat heterogeneity of Missouri and Texas shrublands and adjacent woodland edges are likely ideal habitats for ratsnakes; hence their great importance as predators there. The importance of ratsnakes as predators in the Texas juniper forests suggests these are good snake habitats as well. This might be explained by the low stature of juniper trees; snakes bask in the top of the canopy in these forests, which have the same properties that make edges attractive to snakes (Sperry et al. 2009). The increased importance of fire ants in shrubland versus forest within Texas is consistent with their habitat preference for open disturbed areas (Allen et al. 2004).

The importance of specific predator species likely results from both geographic patterns in the distribution of those species and from their habitat preferences. For example, most species of ground squirrels [e.g., thirteen-lined ground squirrel (Ictidomys tridecemlineatus) and Richardson's ground squirrel (Urocitellus richardsonii)] occur in the western U.S. in open habitats. The most frequent nest predator in Wisconsin and North Dakota grasslands was the thirteen-lined ground squirrel (Pietz et al., chapter 1, this volume). No ground squirrels occurred at the Missouri or Texas sites because only woody habitats were studied there. Tree squirrels occurred in the shrubland and forest habitats in Missouri, Texas, and Georgia but they were not dominant predators.

Our point here, somewhat obvious but until recently not investigated (e.g., Ribic et al. 2009), is that the importance of predator groups and species clearly differs geographically and by habitat. Therefore, different approaches to understanding and potentially mitigating predation will be needed in different geographic regions and habitats.

\section{PREDATOR SPECIFIC APPROACHES TO UNDERSTANDING OR MITIGATING NEST PREDATION}

\section{Mesopredators and Waterfowl Nest Predation}

Waterfowl researchers have for a long time worked on identifying nest predators (e.g., with timelapse photography; Sargeant et al. 1998) and on understanding the interaction of nest predators 
southern latitudes. The southern latitudes also had a more even distribution among predator groups than the northern latitudes (Fig. 2.2).

The decrease in the importance of snakes as a nest predator in northern latitudes is consistent with geographic patterns in snake distributions. While numbers of all species tend to decrease with latitude in North America, numbers of ectotherms decline more steeply than endotherms, and numbers of snake species are negatively correlated with numbers of mammal and bird species (Schall and Pianka 1978). The most commonly detected snake group was the ratsnake (Pantherophis spp.); this group is at its northern range limit in Wisconsin (Christoffel et al. 2000) and does not occur on the Wisconsin study sites or in North Dakota (Trepanowski 2003). In Wisconsin, snakes such as the western foxsnake (Mintonius vulpinus) and gartersnake (Thamnophis spp.) were responsible for grassland bird nest predation, but at a much lower rate than mammals.

Fire ants were only a nest predator in southern latitudes. The imported red fire ant was introduced in Alabama in the 1930s and has spread throughout most of the southern U.S. (Allen et al. 2004). Hence, the pattern in their importance as a nest predator reflects their distribution.

Another geographic pattern relates to cowbirds. Cowbirds were predators at all sites except for forests in Missouri and Georgia (Fig. 2.2). This is somewhat consistent with patterns in their breeding abundances; they are most abundant in the Great Plains and Midwest, with decreasing abundance moving coastward. This pattern in abundance likely reflects their historic distribution in the Great Plains and expansion across North America (Thompson et al. 2000). However, the geographic pattern in the importance of cowbirds as brood parasites (and, by extension, nest predators) may be confounded by habitat (Igl and Johnson 2007).

Other patterns were related to habitat. In the northern grasslands, predation rates by group were very similar for the two areas. At mid-latitudes (Missouri), the most important predator group shifted from snakes in shrublands to mammals in forests, largely due to greater predation by raccoons (Procyon lotor) in forests. The biggest difference among habitats in Texas was the increased importance of cowbirds and fire ants in shrubland; however, in contrast to Missouri, snakes were equally or even slightly more important in forests. These differences all relate to habitat preferences of the predators. Snakes, especially ratsnakes, prefer edge because of benefits for thermoregulation (Blouin-Demers and Weatherhead 2001). The habitat heterogeneity of Missouri and Texas shrublands and adjacent woodland edges are likely ideal habitats for ratsnakes; hence their great importance as predators there. The importance of ratsnakes as predators in the Texas juniper forests suggests these are good snake habitats as well. This might be explained by the low stature of juniper trees; snakes bask in the top of the canopy in these forests, which have the same properties that make edges attractive to snakes (Sperry et al. 2009). The increased importance of fire ants in shrubland versus forest within Texas is consistent with their habitat preference for open disturbed areas (Allen et al. 2004).

The importance of specific predator species likely results from both geographic patterns in the distribution of those species and from their habitat preferences. For example, most species of ground squirrels [e.g., thirteen-lined ground squirrel (Ictidomys tridecemlineatus) and Richardson's ground squirrel (Urocitellus richardsonii)] occur in the western U.S. in open habitats. The most frequent nest predator in Wisconsin and North Dakota grasslands was the thirteen-lined ground squirrel (Pietz et al., chapter 1, this volume). No ground squirrels occurred at the Missouri or Texas sites because only woody habitats were studied there. Tree squirrels occurred in the shrubland and forest habitats in Missouri, Texas, and Georgia but they were not dominant predators.

Our point here, somewhat obvious but until recently not investigated (e.g., Ribic et al. 2009), is that the importance of predator groups and species clearly differs geographically and by habitat. Therefore, different approaches to understanding and potentially mitigating predation will be needed in different geographic regions and habitats.

\section{PREDATOR SPECIFIC APPROACHES TO UNDERSTANDING OR MITIGATING NEST PREDATION}

\section{Mesopredators and Waterfowl Nest Predation}

Waterfowl researchers have for a long time worked on identifying nest predators (e.g., with timelapse photography; Sargeant et al. 1998) and on understanding the interaction of nest predators 
nest success because, as video nest surveillance revealed, other predators were more important (fire ants, snakes, and birds; Conner et al. 2010). These two examples highlight how knowing the identities of the nest predators can lead to success (cowbirds) and not knowing can lead to failure (mesopredators) in direct removal efforts and the challenge of dealing with a diverse predator community versus a single dominant predator.

\section{Potential Indirect Control of Snakes}

A plethora of research on snakes in the Midwest has occurred at least partially because of the confirmation by video surveillance that snakes are important nest predators (Thompson et al. 1999). Recent studies have addressed habitat selection and activity patterns by ratsnakes, racers (Coluber spp.), and prairie kingsnakes (Lampropeltis calligaster calligaster) (Blouin-Demers and Weatherhead 2001, Sperry et al. 2009, Carfagno and Weatherhead 2006, Richardson et al. 2006, Klug et al. 2010), and some studies have directly investigated links between snake activity and habitat use and nest predation (Sperry et al. 2008, 2009; Weatherhead et al. 2010). Other research in the same or nearby areas has found that nest predation is higher in areas with greater fragmentation or amounts of edge (Robinson et al. 1995, Suarez et al. 1997, Heske et al. 2001, Peak 2007, Reidy et al. 2009). In general, these studies have shown that snakes are an important predator of songbird nests, snakes prefer edges, and nest mortality is often high near edges. Snake preference for edges is thought, in part, to be due to the convenience of the mix of sun and shade for thermoregulation. Klug et al. (2010) investigated nest success of grassland birds and habitat selection by bird-eating snakes; they found snakes preferred shrub habitats and that nesting success of grassland birds decreased with increasing shrub cover. However, two other studies that simultaneously studied snakes and nest success found a snake preference for edge but did not find lower nest success there (Sperry et al. 2009, Weatherhead et al. 2010); this suggests the need for further work in this area or alternative hypotheses. In addition to the thermal benefits referred to above, the high structural heterogeneity of shrub habitat compared to grassland may provide snakes with higher prey densities (Carfagno et al. 2006) or protection from predators (Wilgers and Horne 2006).
Direct control of snakes will not be desirable or feasible in many circumstances. Efficient removal of snakes is probably not possible, and snakes are a desired component of many ecosystems and are protected in many states. However, the cumulative work in this area suggests a possible use of indirect habitat manipulation strategies. A plausible management hypothesis for this system is that reducing edge will reduce snake activity or abundance in an area and, thereby, lower nest predation. Klug et al. (2010) speculated that only a small reduction in shrub cover might significantly reduce predation risk on grassland birds. Additional questions are whether this action would lower snake abundance in a landscape or simply shift snake activity elsewhere, to other prey and potentially other birds. Because reducing edge and fragmentation is a common conservation recommendation for addressing low nest survival of passerines in fragmented habitats, there may already be programs in place that could be used to evaluate this hypothesis.

\section{Thirteen-lined Ground Squirrels and Passerine Nest Predation}

Agriculture (including grazing by nonnative ungulates), fire suppression, and urbanization are continuing to change the areas of North America originally composed of prairie into a patchwork of land uses (Askins et al. 2007). Currently, planted or surrogate grasslands dominate the remaining eastern grassland systems (Askins et al. 2007); these surrogate grasslands are composed of Eurasian grass and forb species, are typically associated with agriculture, and include hayfields, pastures, fallow, and old fields (Sample et al. 2003). In Wisconsin, Sample and Mossman (1997) developed a heuristic Bird Conservation Area model to argue that restoring and enhancing both small and large grassland patches within landscapes that already have a high proportion of grassy habitat and little or no woodland would likely have the greatest benefit for grassland birds. Under this model, there was an implicit assumption that woody-edge predators were driving the dynamics of grassland bird populations on small patches (D. Sample, pers. comm.). Removing woody patches/fencerows in the landscape and enlarging grassy habitat patches, then, would reduce a major source of predators and, thus, benefit grassland birds by lowering predation risk. 
However, at the time this model was developed, there was little information about the identities of grassland bird nest predators. The first work in Wisconsin on pastures (Renfrew and Ribic 2003) seemed to confirm that woody-edge predators (specifically raccoons) indeed were responsible for a high proportion of nest predation events; however, there was some indication that a species that lived in the same grassy habitats as the grassland birds, specifically the thirteen-lined ground squirrel, was also an important nest predator. Investigation into the nest predators in a different grassy habitat, Conservation Reserve Program fields (Ribic et al., chapter 10, this volume), provided further evidence of the importance of the thirteen-lined ground squirrel as a major predator on grassland bird nests.

How does this new information impact the Bird Conservation Area model of Sample and Mossman (1997)? In this case, removal of edges to enlarge habitat for grassland birds will also increase habitat for a major grassland nest predator. Thus, the assumed benefit of increased productivity, expected from an assumed decrease in a major predator associated with woody habitat, may not be realized. While the patch size needed for grassland bird populations has been considered (e.g., more than 1,000 ha for prairie fragments; Herkert et al. 2003), the question we may want to ask is what patch size is needed to dilute the effect of the nest predator associated with grassy habitat? We could also consider direct predator control; thirteen-lined ground squirrels are not protected in Wisconsin, and targeted control might reduce nest predation effects for a season or two, allowing a pulse of grassland bird productivity. However, we do not know the effects direct predator control may have on species that feed on the ground squirrel. Thinking about grassland bird management may need to broaden into thinking about multispecies management of the grassland ecosystem.

\section{Concluding Thoughts}

Beginning with the articulation of specific hypotheses concerning predators and edge and fragmentation effects on songbirds (Heske et al. 2001, Thompson et al. 2002) and investigations into the identities of nest predators of songbirds (Pietz et al., chapter 1, this volume), it has become clear that we cannot broadly generalize about nest predation. Besides thinking about birds, we need to remember to take the "predators' view of the landscape" (Kuehl and Clark 2002:1233). This approach is leading to the developing perspective that for songbird conservation, we will need to take a broader system perspective to understand or mitigate songbird nest predation (Thompson 2007, Lahti 2009).

The development of video monitoring technology and its growing application to nest predation studies is finally providing the empirical evidence to demonstrate the need for a broad perspective. Only a few songbird studies have attempted to relate songbird nest predation by predator species or predator groups to environmental variables (Benson et al. 2010, Reidy and Thompson, chapter 11, this volume). Examination of models for particular species or groups of predators has helped discover temporal, habitat, and landscape effects that are often masked by lumping predators. However, for most birds in most landscapes it is not known if productivity is even limiting population growth, and hence if mitigating nest predation should even be considered. We still have many unanswered questions for passerines.

Where nest predation is considered unacceptably high, mitigation of nest predation based on hypotheses that reflect knowledge of predators should be most effective. What tool to use-exclusion, removal, dilution or a combination-should reflect knowledge of both birds and their nest predators. We are not advocating predator control but simply recognizing it is an option that has been locally successful when appropriately targeted. We believe that using knowledge of nest predators and their habitat requirements will be more effective than direct predator control in managing habitats for passerines, whether this is called indirect predator control or just good bird habitat management. Knowledge of the importance of predators, and in what circumstances nest predation is pathologically high, leads to credible and testable hypotheses about what has changed in habitats and landscapes and how it can be approached from a broader conservation perspective. Developing credible management hypotheses and evaluating these in an adaptive management approach may be helpful in resolving some of these unknowns and moving forward with effective conservation. This approach is currently being used by the U.S. Fish and Wildlife Service in Strategic Habitat Conservation (U.S. Fish and Wildlife Service 2009). Finally, 
investigation of hypotheses concerning nest predation will be more informative if it takes a systems approach and addresses specific aspects of predator ecology (Teunissen et al. 2008). Large samples of predation events for which we know the identity of predators will be required; video technology is essential for this task.

\section{ACKNOWLEDGMENTS}

Our thanks to research collaborators R. B. Renfrew, J. L. Nack, M. J. Guzy, T. J. Anderson, K. S. Ellison, D.W. Sample, J. L. Reidy, M. M. Stake, D. E. Burhans, and L. M. Conner. We thank all the field technicians who helped collect the data used in this paper and the private land owners who allowed us onto their properties. Camera systems were built by J. Christensen, J. Dadisman, and K. S. Ellison. We thank P. J. Pietz, D. Donner, K. Bakker, and two anonymous reviewers for their comments on previous versions of this manuscript. Mention of trade names or commercial products does not constitute endorsement for use by the U.S. government. Financial support was provided by the U.S. Army, U.S. Forest Service, U.S. Geological Survey, U.S. Fish and Wildlife Service Region 3 Nongame Bird Conservation Program, The Nature Conservancy, and the Wisconsin Department of Natural Resources. We thank the Department of Forest and Wildlife Ecology, University of Wisconsin, Madison, for assistance with publication expenses.

\section{LITERATURE CITED}

Allen, C. R., D. M. Epperson, and A. S. Garmestani. 2004. Red imported fire ant impacts on wildlife: a decade of research. American Midland Naturalist 152:88-103.

Askins, R. A., F. Chavez-Ramirez, B. C. Dale, C. A. Haas, J. R. Herkert, F. L. Knopf, and P. D. Vickery. 2007. Conservation of grassland birds in North America: understanding ecological processes in different regions. Ornithological Monographs No. 64.

Benson, T. J., J. D. Brown, and J. C. Bednarz. 2010. Identifying predators clarifies predictors of nest success in a temperate passerine. Journal of Animal Ecology 79:225-234.

Blouin-Demers, G., and P. J. Weatherhead. 2001. Habitat use by black rat snakes (Elaphe obsolete obsolete) in fragmented forests. Ecology 82:2882-2896.

Carfagno, G. L. F., E. J. Heske, and P. J. Weatherhead. 2006. Does mammalian prey abundance explain forest-edge use by snakes? Ecoscience 13:293-297.

Chodachek, K. D., and M. J. Chamberlain. 2006. Effects of predator removal on upland nesting ducks in North Dakota grassland fragments. Prairie Naturalist 38:25-37.
Christoffel, R., R. Hay, and L. Ramirez. 2000. Snakes of Wisconsin. PUB-ER-100 00. Wisconsin Department of Natural Resources, Bureau of Endangered Resources, Madison, WI.

Conner, L. M., J. C. Rutledge, and L. L. Smith. 2010. Effects of mesopredators on nest survival of shrubnesting songbirds. Journal of Wildlife Management 74:73-80.

Emery R. B., D. W. Howerter, L. M. Armstrong, M. G. Anderson, J. H. Devries, and B. L. Joynt. 2005. Seasonal variation in waterfowl nesting success and its relation to cover management in the Canadian prairies. Journal of Wildlife Management 69:1181-1193.

Garrettson, P. R., and F. C. Rohwer. 2001. Effects of mammalian predator removal on production of upland-nesting ducks in North Dakota. Journal of Wildlife Management 65:398-405.

Granfors, D. A., P. J. Pietz, and L. A. Joyal. 2001. Frequency of egg and nestling destruction by female Brown-headed Cowbirds at grassland nests. Auk 118:765-769.

Greenwood, R. J., and M. A. Sovada. 1996. Prairie duck populations and predation management. Transactions of the North American Wildlife and Natural Resources Conference 61:31-42.

Herkert, J. R., D. L. Reinking, D. A. Wiedenfeld, M. Winter, J. L. Zimmerman, W. E. Jensen, E. J. Finck, R. R. Koford, D. H. Wolfe, S. K. Sherrod, M. A. Jenkins, J. Faaborg, and S. K. Robinson. 2003. Effects of grassland fragmentation on the nesting success of breeding birds in the mid-continental United States. Conservation Biology 17:587-594.

Heske, E. J., S. K. Robinson, and J. D. Brawn. 2001. Nest predation and neotropical migrant songbirds: piecing together the fragments. Wildlife Society Bulletin 29:52-61.

Hoekman, S. T., L. S. Mills, D. W. Howerter, J. H. Devries, and I. J. Ball. 2002. Sensitivity analyses of the life cycle of midcontinent Mallards. Journal of Wildlife Management 66:883-900.

Igl, L. D., and D. H. Johnson. 2007. Brown-headed Cowbird, Molothrus ater, parasitism and abundance in the northern Great Plains. Canadian Field-Naturalist 121:239-255.

Jimenez, J. E., and M. R. Conover. 2001. Ecological approaches to reduce predation on ground-nesting gamebirds and their nests. Wildlife Society Bulletin 29:62-69.

Klug, P. E., S. L. Jackrel, and K. A. With. 2010. Linking snake habitat use to nest predation risk in grassland birds: the dangers of shrub cover. Oecologia 162:803-813.

Kostecke, R. M, S. G. Summers, G. H. Eckrich, and D. A. Cimprich. 2005. Effects of Brown-headed 
Cowbird (Molothrus ater) removal on Black-capped Vireo (Vireo atricapilla) nest success and population growth at Fort Hood, Texas. Pp. 28-37 in C. P. Ortega, J. F. Chace, and B. D. Peer (editors), Management of cowbirds and their hosts: balancing science, ethics, and mandates. Ornithological Monographs No. 57.

Kuehl, A. K., and W. R. Clark. 2002. Predator activity related to landscape features in northern Iowa. Journal of Wildlife Management 66:1224-1234.

Kus, B. E., and M. J. Whitfield. 2005. Parasitism, productivity, and population growth: response of Least Bell's Vireo (Vireo bellii pusillus) and Southwestern Willow Flycatchers (Empidonax traillii extimus) to cowbird (Molothrus spp.) control. Pp. 16-27 in C. P. Ortega, J. F. Chace, and B. D. Peer (editors), Management of cowbirds and their hosts: balancing science, ethics, and mandates. Ornithological Monographs No. 57.

Lahti, D. C. 2009. Why we have been unable to generalize about bird nest predation. Animal Conservation 12:279-281.

Martin, T. E. 1988. Processes organizing open-nesting bird assemblages: competition or nest predation? Evolutionary Ecology 2:37-50.

Martin, T. E. 1995. Avian life history evolution in relation to nest sites, nest predation, and food. Ecological Monographs 65:101-126.

Nelson, H. K. 2001. Impact of predation on avian recruitment: an introduction. Wildlife Society Bulletin 29:2-5.

Newton, I. 1998. Population limitation in birds. Academic Press, London, England.

Peak, R. G. 2007. Forest edges negatively affect Golden-cheeked Warbler nest survival. Condor 109:628-637.

Phillips, M. L., W. R. Clark, M. A. Sovada, D. J. Horn, R. R. Koford, and R. J. Greenwood. 2003. Predator selection of prairie landscape features and its relation to duck nest success. Journal of Wildlife Management 67:104-114.

Pieron, M. R., and F. C. Rohwer. 2010. Effects of largescale predator reduction on nest success of upland nesting ducks. Journal of Wildlife Management 74:124-132.

Reidy, J. L., F. R. Thompson III, and R. G. Peak. 2009. Factors affecting Golden-cheeked Warbler nest survival in urban and rural landscapes. Journal of Wildlife Management 73:407-413.

Renfrew, R. B., and C. A. Ribic. 2003. Grassland passerine nest predators near pasture edges identified on videotape. Auk 120:371-383.

Renfrew, R. B., C. A. Ribic, and J. L. Nack. 2005. Edge avoidance by nesting grassland birds: a futile strategy in a fragmented landscape. Auk 122:618-636.
Reynolds, R. E., T. L. Shaffer, R. W. Renner, W. E. Newton, and B. D. J. Batt. 2001. Impact of the Conservation Reserve Program on duck recruitment in the U.S. Prairie Pothole Region. Journal of Wildlife Management 65:765-780.

Ribic, C. A., R. R. Koford, J. R. Herkert, D. H. Johnson, N. D. Niemuth, D. Naugle, K. K. Bakker, D.W. Sample, and R.B. Renfrew. 2009. Area sensitivity in North American grassland birds: patterns and processes. Auk 126:233-244.

Richardson, M. L., P. J. Weatherhead, and J. D. Brawn. 2006. Habitat use and activity of prairie kingsnakes (Lampropeltis calligaster calligaster) in Illinois. Journal of Herpetology 40:423-428.

Ricklefs, R. E. 1969. An analysis of nesting mortality in birds. Smithsonian Contributions to Zoology 9:1-48.

Robinson, S. K., F. R. Thompson III, T. M. Donovan, D. R. Whitehead, and J. Faaborg. 1995. Regional forest fragmentation and the nesting success of migratory birds. Science 267:1987-1990.

Rothstein, S. I., and B. D. Peer. 2005. Conservation solutions for threatened and endangered cowbird (Molothrus spp.) hosts: separating fact from fiction. Pp. 98-114 in C. P. Ortega, J. F. Chace, and B. D. Peer (editors), Management of cowbirds and their hosts: balancing science, ethics, and mandates. Ornithological Monographs No. 57.

Sample, D. W., and M. J. Mossman. 1997. Managing habitat for grassland birds, a guide for Wisconsin. Wisconsin Department of Natural Resources, Madison, WI.

Sample, D. W., C. A. Ribic, and R. B. Renfrew. 2003. Linking landscape management with the conservation of grassland birds in Wisconsin. Pp. 359-385 in J. A. Bissonette and I. Storch (editors), Landscape ecology and resource management: linking theory with practice. Island Press, Washington, DC.

Sargeant, A. B., S. H. Allen, and R. T. Eberhardt. 1984. Red fox predation on breeding ducks in midcontinent North America. Wildlife Monographs 89:1-41.

Sargeant, A. B., R. J. Greenwood, M.A. Sovada, and T. L. Shaffer. 1993. Distribution and abundance of predators that affect duck production: Prairie Pothole Region (version 16JUL97). Resource Publication No. 194. U.S. Fish and Wildlife Service, Jamestown, ND. Northern Prairie Wildlife Research Center Online. <http://www.npwrc.usgs.gov/resource/birds/ predator/index.htm> (24 March 2010).

Sargeant, A. B., M. A. Sovada, and R. J. Greenwood. 1998. Interpreting evidence of depredation of duck nests in the Prairie Pothole Region. U.S. Geological Survey, Northern Prairie Wildlife Research Center, Jamestown, ND, and Ducks Unlimited, Inc., Memphis, TN. 
Schall, J. J., and E. R. Pianka. 1978. Geographic trends in numbers of species. Science 201:679-686.

Sovada, M. A., R. M. Anthony, and B. D. J. Batt. 2001. Predation on waterfowl in arctic tundra and prairie breeding areas: a review. Wildlife Society Bulletin 29:6-15.

Sovada, M. A., A. B. Sargeant, and J. W. Grier. 1995. Differential effects of coyotes and red foxes on duck nest success. Journal of Wildlife Management 59:1-8.

Sovada, M. A., M. C. Zicus, R. J. Greenwood, D. P. Rave, W. E. Newton, R. O. Woodward, and J. A. Beiser. 2000. Relationships of habitat patch size to predator community and survival of duck nests. Journal of Wildlife Management 64:820-831.

Sperry, J. H., D. A. Cimprich, R. G. Peak, and P. J. Weatherhead. 2009. Is nest predation on two endangered bird species higher in habitats preferred by snakes? Ecoscience 16:111-118.

Sperry, J. H., R. G. Peak, D. A. Cimprich, and P. J. Weatherhead. 2008. Snake activity affects seasonal variation in nest predation risk for birds. Journal of Avian Biology 39:379-383.

Suarez, A. V., K. S. Pfennig, and S. K. Robinson. 1997. Nesting success of a disturbance-dependent songbird on different kinds of edges. Conservation Biology 11:928-935.

Teuniseen, W., H. Schekkerman, F. Willems, and F. Majoor. 2008. Identifying predators of eggs and chicks of Lapwing Vaneullus vanellus and Blacktailed Godwit Limosa limosa in the Netherlands and the importance of predation on wader reproductive output. Ibis 150(Suppl. 1):74-85.

Thompson, F. R., III. 2007. Factors affecting nest predation on forest birds in North America. Ibis 149(Suppl. 2):98-109.

Thompson, F. R., III, and D. E. Burhans. 2003. Predation of songbird nests differs by predator and between field and forest habitats. Journal of Wildlife Management 67:408-416.

Thompson, F. R., III, W. D. Dijak, and D. E. Burhans. 1999. Video identification of predators at songbird nests in old fields. Auk 116:259-264.
Thompson, F. R., III, T. M. Donovan, R. M. DeGraaf, J. Faaborg, and S. K. Robinson. 2002. A multi-scale perspective of the effects of forest fragmentation on birds in eastern forests. Pp. 8-19 in T. L. George and D. S. Dobkin (editors), Effects of habitat fragmentation on birds in western landscapes: contrasts with paradigms from the Eastern United States. Studies in Avian Biology No. 25. Cooper Ornithological Society, Allen Press, Inc., Lawrence, KS.

Thompson, F. R., III, S. K. Robinson, T. Donovan, J. Faaborg, and D. W. Whitehead. 2000. Biogeographic, landscape, and local constraints on cowbirds: the importance of scale to managing brood parasitism. Pp. 271-279 in J. N. M. Smith, T. L. Cook, S. I. Rothstein, S. K. Robinson, and S. G. Sealy (editors), Ecology and management of cowbirds and their hosts. University of Texas Press, Austin, TX.

Trepanowski, P. 2003. Animal diversity web, Elaphe obsoleta. <http://animaldiversity.ummz.umich.edu/ site/accounts/information/Elaphe_obsoleta.html> (21 April 2010).

U.S. Fish and Wildlife Service. 2009. Strategic habitat conservation. <http://www.fws.gov/science/ strategichabitatconservation.html> (16 April 2010).

Weatherhead, P. J., and G. Blouin-Demers. 2004. Understanding avian nest predation: why ornithologists should study snakes. Journal of Avian Biology 35:185-190.

Weatherhead, P. J., G. L. F. Carfagno, J. H. Sperry, J. D. Brawn, and S. K. Robinson. 2010. Linking snake behavior to nest predation in a Midwestern bird community. Ecological Applications 20:234-241.

Wilgers D. J., and E. A. Horne. 2006. Effects of different burn regimes on tallgrass prairie herpetofaunal species diversity and community composition in the Flint Hills, Kansas. Journal of Herpetology 40:73-84.

Winter, M., D. H. Johnson, and J. Faaborg. 2000. Evidence for edge effects on multiple levels in tall grass prairie. Condor 102:256-266. 